\title{
Changes in the Adriatic oceanographic properties induced by the Eastern Mediterranean Transient
}

\author{
I. Vilibić, S. Matijević, J. Šepić, and G. Kušpilić \\ Institute of Oceanography and Fisheries, Split, Croatia \\ Correspondence to: I. Vilibić (vilibic@izor.hr) \\ Received: 3 January 2012 - Published in Biogeosciences Discuss.: 20 January 2012 \\ Revised: 18 April 2012 - Accepted: 11 May 2012 - Published: 11 June 2012
}

\begin{abstract}
Long-term time series of physical and chemical parameters collected between 1960 and 2010 along the Palagruža Sill transect, Middle Adriatic Sea, have been investigated in terms of average water properties and their variability. Nutrients, especially orthophosphates, reached rather high levels of concentration below the euphotic zone between 1991 and 1998, the highest levels in the investigated period. Simultaneously, the N:P ratio, which is normally higher than 25:1, decreased to values less than 16:1 in the euphotic zone, indicating a switch from typical phosphorus to nitrogen- limited preconditioning for the primary production. Higher-than-usual nutrient levels peaking in the mid1990s, coupled with lower-than-usual temperature, salinity, dissolved oxygen and $\mathrm{pH}$ values, are presumably related to the flow of the nutrient richer Western Mediterranean waters to the Adriatic below the euphotic layer. These waters, which keep their footprint in the N:P ratio, enter the Adriatic during the anticyclonic phase of the Bimodal Adriatic-Ionian Oscillation (BiOS), which has been uniquely strengthened by the Eastern Mediterranean Transient occurring in the early 1990s. This hypothesis should be confirmed through targeted research and modelling exercises, as it is highly relevant for the biogeochemistry of the Adriatic Sea.
\end{abstract}

\section{Introduction}

Starting with the 1980s through the POEM program (Physical Oceanography of the Eastern Mediterranean; MalanotteRizzoli et al., 1997), the knowledge about the hydrography, circulation, and basin-scale, local and mesoscale processes of the Eastern Mediterranean has been improved a lot. A classical picture of the Eastern Mediterranean portrays it as a concentration basin, where an anti-estuarine circulation is the result of dense and deep water convection: (i) Levantine Intermediate Water (LIW) is generated largely in the Rhodes Gyre and the Levantine Basin (Lascaratos et al., 1993), flowing in a subsurface layer towards the northernmost basin (Adriatic) and the Western Mediterranean, while (ii) dense water generation sites are located in the Adriatic Sea; the dense water sinks to the deep Ionian Sea and the Levantine Basin. However, an abrupt change, called the Eastern Mediterranean Transient (EMT, Roether et al., 1996, 2007; Klein et al., 1999, 2000) occurred in the early 1990s. The EMT was characterized by a massive generation of dense water in the Aegean Sea driven by exceptional heat losses and winds (Josey, 2003). The EMT generated a shift of deep water characteristics (Kress et al., 2003) and impacted the circulation, particularly of the Ionian Sea, where the anticyclonic circulation was strengthened during the EMT phase, and turned over to cyclonic in 1997 during the EMT relaxation phase (Borzelli et al., 2009).

Gačić et al. (2010) suggested a generalised concept of circulation fluctuations of the central Mediterranean, hypothesizing that the Ionian upper circulation variability is driven by internal dynamics. Namely, formation of dense waters in the Adriatic Sea, the North Adriatic Dense Water (NAdDW, Vilibić and Supić, 2005) and the Adriatic Deep Water (ADW, Vilibić and Orlić, 2001) and its spreading to the deep Ionian Sea influence vorticity balance there, causes a shrinking of the water column along the western perimeter, changes geostrophic balance between the perimeter and the inner Ionian, and induces anticyclonic circulation. The anticyclonic circulation drags a branch of the modified Atlantic water (MAW) towards the Adriatic. The MAW is characterised by lower salinity, temperature and density, resulting in 
generation of the NAdDW and ADW of lower density. These waters then flow towards the northwestern Ionian perimeter and, together with less dense MAW lying above them, stretch the water column and change geostrophic balance, resulting in a shift of the circulation to the cyclonic one. This important concept called Bimodal Adriatic-Ionian Oscillation (BiOS), which was introduced recently for the central Mediterranean Basin, was further extended towards the Levantine Basin and the EMT preconditioning (Gačić et al., 2011), and was found to explain a number of known phenomena such as decadal salinity oscillations in the Adriatic called the Adriatic ingressions (Buljan, 1953; Civitarese et al., 2010) and the decadal variation of the MAW meandering in the Ionian Sea (Malanotte-Rizzoli et al., 1997).

These physical concepts have an important consequence to the biogeochemical properties and biodiversity of the whole Eastern Mediterranean Basin. Namely, it is known that the Eastern Mediterranean is ultra-oligotrophic area, with high $\mathrm{N}:$ P ratio in deep waters, about 28:1 (Krom et al., 1991, 2004, 2010). Therefore, the primary production is low and limited by phosphorus (Siokou-Frangou et al., 2010). The only exception is the northernmost Adriatic, where high river nutrient loads are responsible for the phytoplankton blooms and eutrophication of this area (Degobbis and Gilmartin, 1990; Degobbis et al., 2000). Krom et al. (2004) propose that high $\mathrm{N}: \mathrm{P}$ ratio is kept because there is no significant denitrification in either the intermediate water or in the sediments, maintained by anti-estuarine flow at the Straits of Sicily. The Western Mediterranean differs a lot: the concentrations of orthophosphates and nitrates+nitrites are higher about 5 and 3 times than in the Eastern Mediterranean in euphotic layer, respectively, and about 2.2 and 1.6 times in intermediate and deep waters, respectively, resulting in strong nutrient horizontal gradients between the Eastern and the Western Mediterranean over Sicily Strait (Pujo-Pay et al., 2011). A number of authors attribute the gradient to the difference in the allochthonous nutrient sources in terms of quantity and quality (e.g. Ribera d'Alcala et al., 2003; Ludwig et al., 2010), and to biogeochemical processes rather than to circulation itself (Crispi et al., 2001; Thingstad et al., 2005).

However, the circulation may be quite important on interannual and decadal scales over the specific areas of the Mediterranean Basin like the Adriatic, as horizontal or vertical advection and displacement of nutrients may cause shifts in primary production at specific locations, such as the deepconvection locations, e.g. the South Adriatic Pit where phytoplankton blooms follow the deep convection events (Gačić et al., 2002; Vilibić and Šantić, 2008). Aside for that, the Adriatic Sea upper layer circulation is driven by the freshwater input, particularly of the northern Adriatic rivers that result in a cyclonic surface circulation, with the outflowing West Adriatic Current (WAC) along the western coastline and the inflowing LIW and the surface Ionian waters along the eastern coastline. Although the nutrient load by the northern Adriatic rivers is significant, this impact is mainly restricted to the northern Adriatic and the WAC (Grilli et al., 2005; Polimene et al., 2006; Solidoro et al., 2009), as the nutrients are normally consumed very fast during their transport towards the southeast and the open Adriatic (Campanelli et al., 2011). The same, i.e. fast consumption of nutrients and restriction of primary production to the coast, has been found around the eastern Adriatic freshwater inputs (Marini et al., 2010; Ninčević Gladan et al., 2010; Viličić et al., 2011). By contrast, the open Adriatic water nutrient load is mostly controlled by the inflowing waters coming from the Ionian Sea (Šolić et al., 2008).

Therefore, the inflow of the intermediate waters from the Ionian Sea, mainly of the LIW, is a major supplier of the open Adriatic nutrients, and is found to influence the Adriatic long-term productivity (Marasović et al., 1995, 2005; Grbec et al., 2009). An increase in bacterial abundances as well as in bacterial production (Šolić et al., 2008) has been found to coincide with the inflow of the LIW. Civitarese et al. (2010) applied the BiOS concept to the observed biological changes in the Adriatic and found a correlation between high salinity periods and allochthonous organisms coming from the Eastern Mediterranean. Furthermore, they found correlation between allochthonous organisms coming from the Western Mediterranean and low salinity periods; however, their data have been largely restricted to the last 20 years. The discovery of the Western Mediterranean organisms in the mid-1990s in the Adriatic favours the hypothesis that the Western Mediterranean waters entered the Adriatic during these years; this hypothesis is further supported by salinity and nutrient load being out of phase in the mid-1990s in the Southern Adriatic Pit and the Ionian Sea (Civitarese et al., 2010).

Following the studies by Gačić et al. (2010) and Civitarese et al. (2010), our study attempts to test the relevance of the BiOS mechanism and its impact on the Adriatic Sea through an introduction of long-term physical and nutrient data collected between 1960 and 2010 at the Palagruža Sill transect (Fig. 1). The data have been collected through permanent monitoring programme, covering the open and the eastern coastal Adriatic waters. In addition, our data allow for an assessment of the uniqueness of the EMT in terms of its impact on the biogeochemical properties of the Adriatic Sea. In Sect. 2 data and their availability are presented; in Sect. 3 the series and average values of all parameters at the profile compared to the 1991-1998 period are displayed; in Sect. 4 our findings are discussed in the light of existing hypotheses, and summary and major conclusions are given in Sect. 5 .

\section{Material and methods}

The investigated area, the Palagruža Sill (Fig. 1), is one of the Adriatic transects that have been monitored regularly since mid last century. The importance of its position in tracing the Adriatic circulation and water masses has been recognized by a number of authors (e.g. Buljan and Zore-Armanda, 1976; 


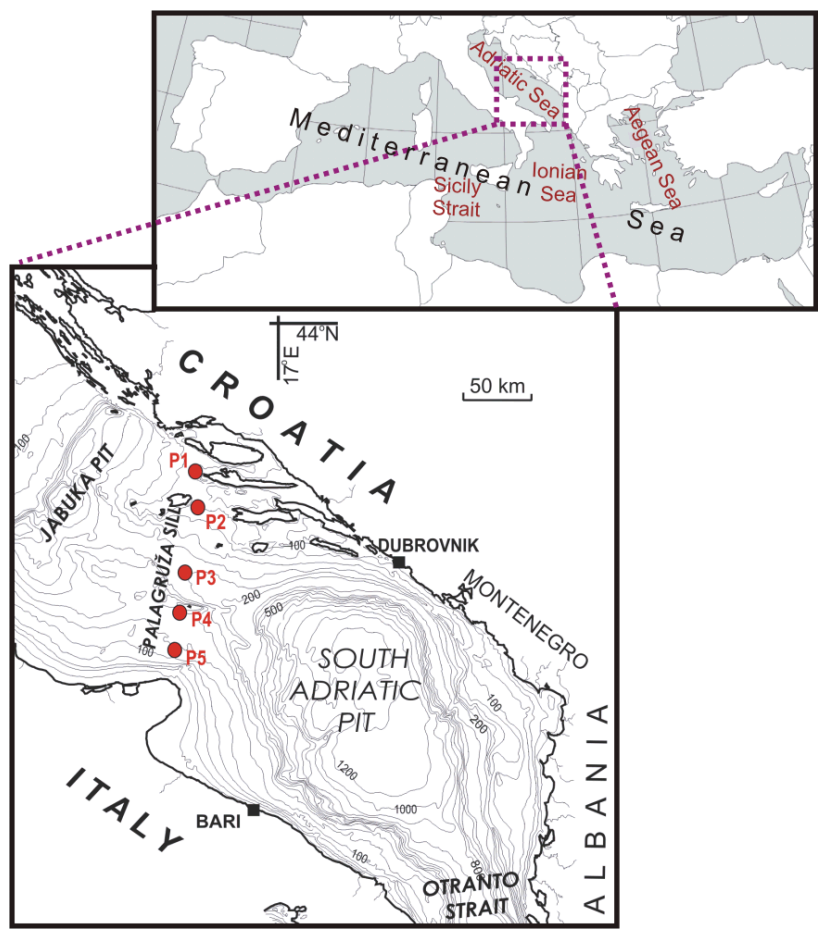

Fig. 1. The investigated area, with locations of stations (P1 to P5) along the Palagruža Sill transect.

Vilibić et al., 2004). The Palagruža Sill separates circular 1200-m deep South Adriatic Pit from the 280-m deep Jabuka Pit multi-depression system and the shallow northern Adriatic. We examined long- term temperature, salinity, dissolved oxygen (DO), orthophosphate, total inorganic nitrogen (TIN) and orthosilicate concentration data measured at 5 permanent stations at standard oceanographic depths $(0,10,20$, $30,50,75,100,150$, bottom) from 1960 to 2010. Apparent oxygen utilization (AOU) has been used for quantifying the DO changes, being the difference between the measured dissolved oxygen concentration and its equilibrium saturation concentration, and measuring cumulative biological activity affecting the DO since its last contact with the atmosphere. The data were collected monthly (stations P1 and P2) or seasonally (stations P3 to P5) in time intervals indicated in Fig. 2. Altogether 478, 542, 186, 177 and 173 surveys were carried out at stations P1 to P5, respectively, with some parameters collected over the full time interval and others over a fraction of the full time interval. Temperature and salinity have been collected at all stations during all cruises; dissolved oxygen and orthophosphates have not been determined in the first decades at stations P3 and P4; TIN data do not cover the first 10-20 years at P1, P2, and P5, while orthosilicate data cover only the last 25 years of the interval or less.

Sampling methodology for some variables was changed during the study period, and the consistency of the data

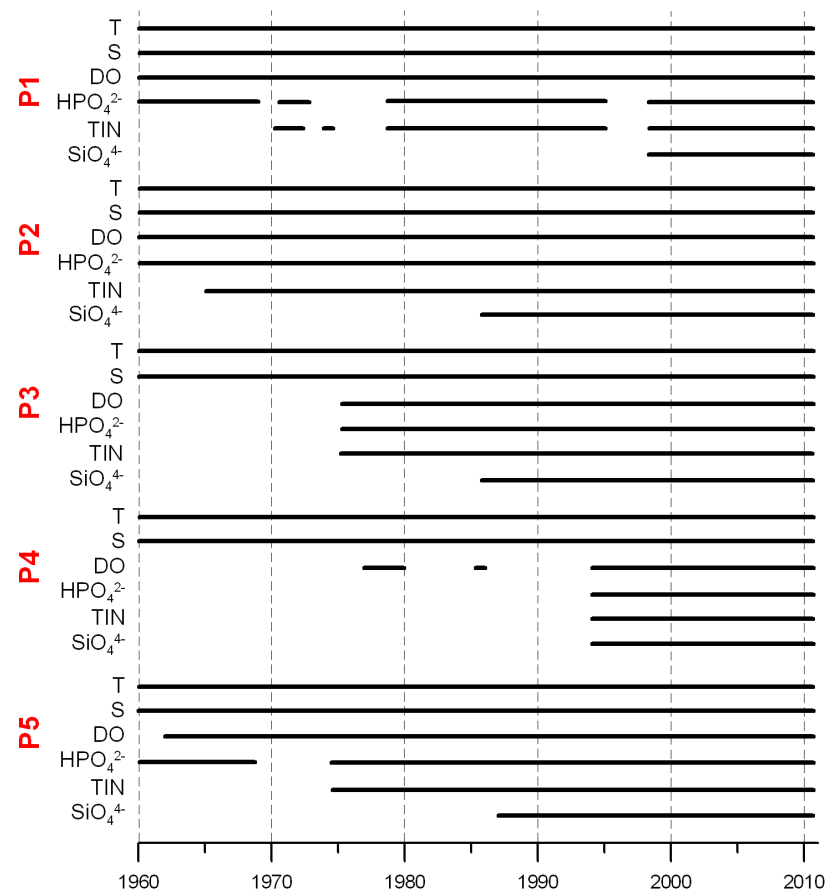

Fig. 2. Availability of the data collected at the Palagruža Sill transect.

(shifts, drifts) between periods was checked through statistical procedures and through calibration experiments that were carried out during a number of research cruises when transitions in methodology occurred. The temperature and salinity were measured with Nansen-bottles until 1998. Reversing thermometers with an accuracy of $\pm 0.02^{\circ} \mathrm{C}$ were used for temperature measurements. Salinity measurements were obtained by titration with $\mathrm{AgNO}_{3}$ (with an accuracy for chlorinity of \pm 0.01 ) until the $1980 \mathrm{~s}$, when the use of a portable induction salinometer RS-10, Beckman Industrial, was introduced (with an accuracy of \pm 0.003 ). After 1998, IDRONAUT 316 CTD and Seabird-25 CTD probes were used to measure temperature and salinity, with accuracy values of $0.003{ }^{\circ} \mathrm{C}$ and $0.002^{\circ} \mathrm{C}$ for temperature, $0.0003 \mathrm{~S} \mathrm{~m}^{-1}$ and $0.0003 \mathrm{~S} \mathrm{~m}^{-1}$ for conductivity, and $0.05 \%$ and $0.1 \%$ of the full-scale range for pressure. Dissolved oxygen was determined using classical Winkler titration (Grasshof, 1976) throughout the study period with an accuracy of $\pm 2 \mu \mathrm{moll}^{-1}$. Concentrations of dissolved inorganic nutrients, including orthophosphate, nitrate, nitrite and ammonia salts as well as orthosilicate, were determined spectrophotometrically according to Strickland and Parsons (1972) until the 1970s. AutoAnalyzer I, II and III colorimeters (Technicon, Bran \& Luebbe, Seal Analytical) were used subsequently, following modified methods based on those proposed by Grasshoff (1976). pH values were determined sporadically at stations P2 and P5 between 1974 and 2002, following the method proposed by Strickland and Parsons (1972). $\mathrm{pH}$ were measured potentiometrically by using glass 


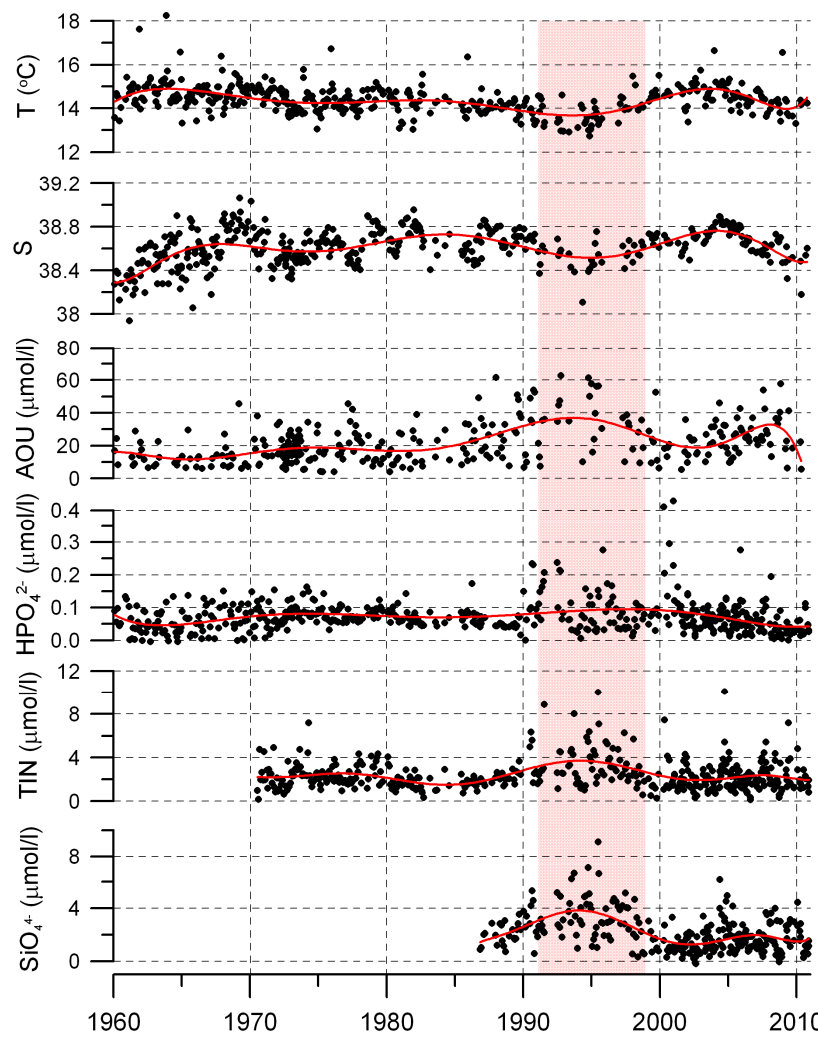

Fig. 3. Time series of temperature, salinity, AOU, orthophosphates, TIN, and orthosilicates at the bottom of the station P2 (100 m). Seasonal signal is removed from the series. Full line stands for the polynomial fitting of seventh order, while the 1991-1998 period is marked by shadow.

electrodes (Radiometer, Beckman, Mettler, Methrom) calibrated with NIST buffer solution standards prior to every set of measurements, and reported as total scale. Calibration and measurements were performed at controlled temperature of $20^{\circ} \mathrm{C}$ according to Strickland and Parsons (1972). The methodology of the $\mathrm{pH}$ data determination introduced in 1970s was retained during the whole period to keep the series homogeneous, regardless of changes in methodology introduced in the meantime.

The data quality was checked by using min-max conditions for each parameter, and by imposing a threshold to the spikes and rapid changes along the vertical for each parameter. Significant seasonality in some parameters like temperature, which normally occurs in the upper layer, has been removed from the series by a year-day least squares fitting using Gauss-Newton algorithm of a combination of 12- and 6-month sinusoidal functions applied to each series. The procedure was separately applied on each station, depth and parameter.

The largest seasonal variance was found for temperature, ranging from $90 \%$ of the total variance at the surface $(0 \mathrm{~m})$ down to $20 \%$ at $170 \mathrm{~m}$ depth. AOU seasonal variance was

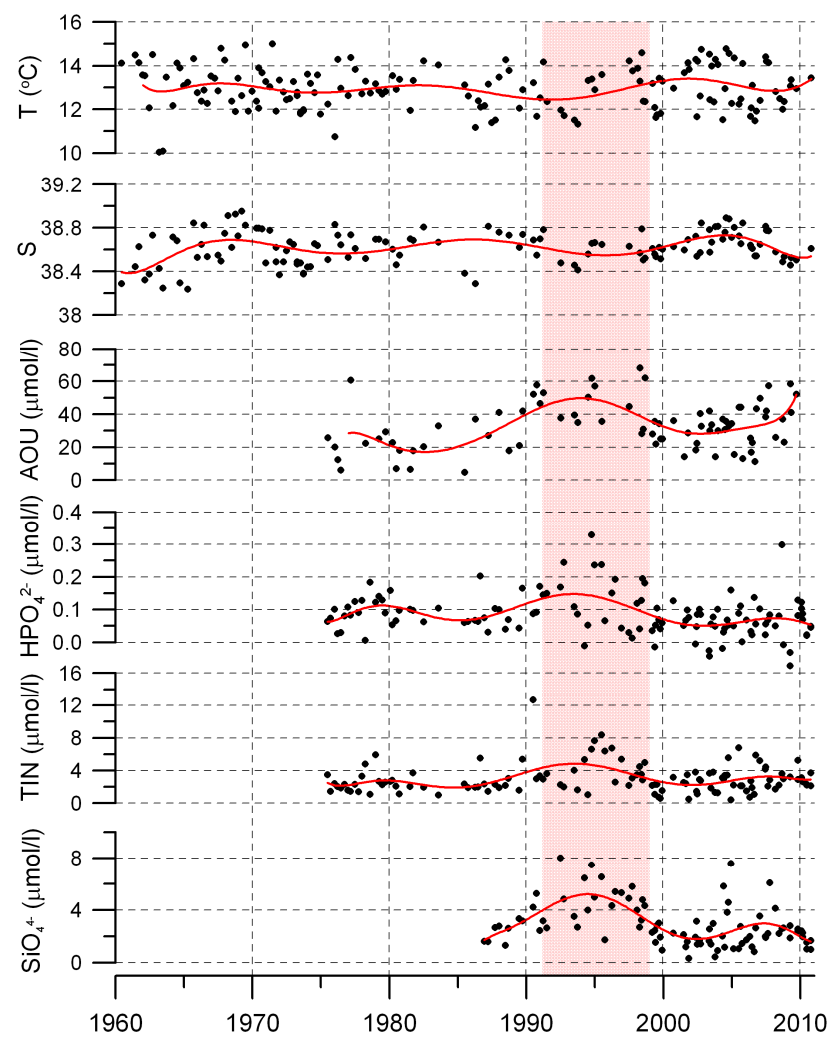

Fig. 4. As in Fig. 3, but for station P3 (170 m).

the largest at $20-30 \mathrm{~m}$, up to $45 \%$ of the total variance, decreasing towards the surface and the bottom. Salinity seasonal variance was the largest at station P1 (20-30\%), influenced by seasonal changes in the eastern Adriatic river discharges. Seasonal variances in nutrients were relatively low, less than $20 \%$; however, the removal of the seasonality increased the significance levels estimated by the analyses.

Differences between overall averages of parameters (the data collected between 1960 and 2010) and averages of the data collected between 1991 and 1998 (the EMT period) have been analyzed. The initial year (1991) for the period of the EMT influence on the Adriatic properties was selected from the available literature, which documents the triggering of the EMT in winters of the early 1990s (Klein et al., 1999). The last year, 1998, has been chosen following the 1997 change from the anticyclonic to cyclonic circulation in the Ionian Sea (Borzelli et al., 2009). The significance level of difference of two periods was tested with unpaired t-test.

\section{Results}

Time series of all de-seasoned parameters show a noteworthy variability, but also a clear interannual and multidecadal variability over some intervals. Deep temperatures at all parts of the transect (Figs. 3 to 5) show an interchange of several maxima and minima, with the most prominent minimum and 


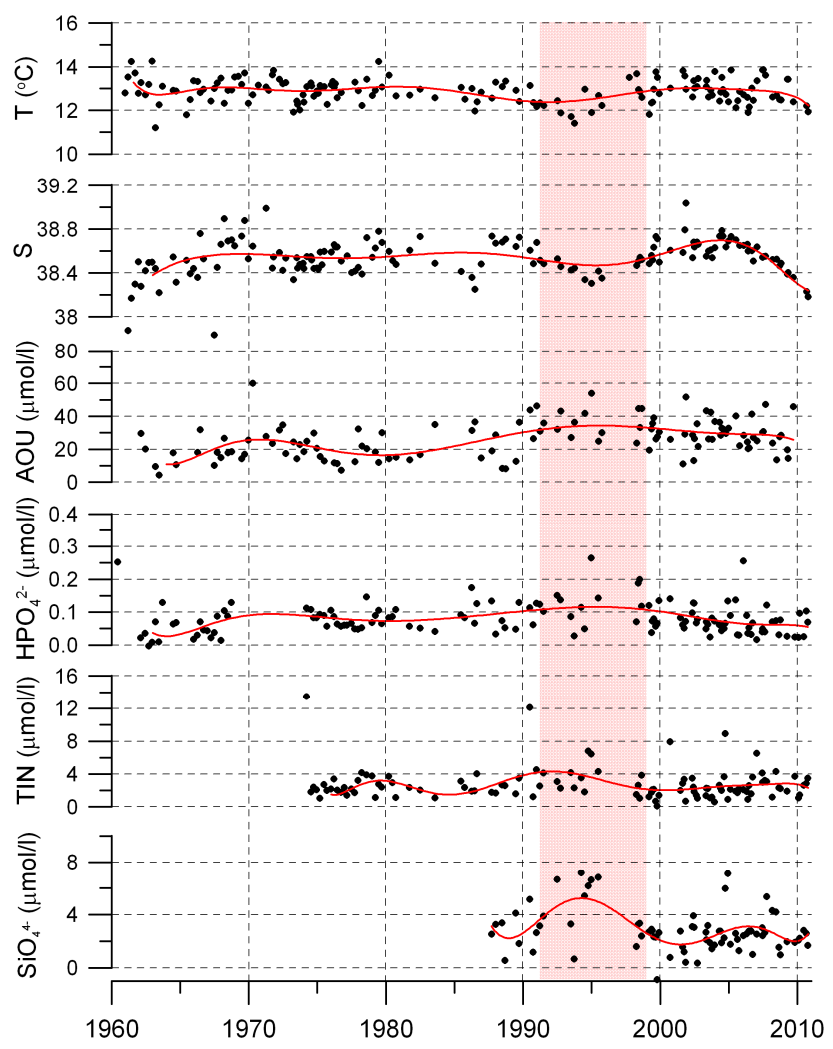

Fig. 5. As in Fig. 3, but for station P5 (115 m).

maximum occurring in the last two decades - especially over the northern part of the transect (Fig. 3). Temperature minimum in the early 1990s was stretching over the transect in deep layers (Figs. 4 and 5) and was followed by a strong temperature increase towards the early 2000s. This temperature shift was already documented for the South Adriatic (Vilibić et al., 2011) and was recognized as a result of the Bimodal Adriatic-Ionian Oscillation (BiOS, Gačić et al., 2010). The minimum in temperature is accompanied by the minimum in salinity in the early 1990s. This minimum is a part of the known salinity fluctuations in the Adriatic (so-called Adriatic ingressions, Buljan, 1953; Civitarese et al., 2010): salinity oscillates between 38.4 and 38.9 , aside from the isolated minimum present at the beginning of the series, in the early 1960s.

Although AOU has positive trends over the whole interval, it follows the same oscillatory pattern as temperature and salinity. The most prominent AOU maximum can be found in the early 1990s, when the values in deep waters increased to more than $40 \mu \mathrm{moll}^{-1}$ (Fig. 4). After the early 1990s, the deep AOU values decreased a bit, becoming stable at values around $15-40 \mu \mathrm{moll}^{-1}$. Aside the mid-1990s anomaly, quite strong and significant positive trends in AOU values may be found over the whole transect, being the largest in deep waters (between 0.35 and $0.50 \mu \mathrm{moll}^{-1} \mathrm{yr}^{-1}$ ). The trends de-
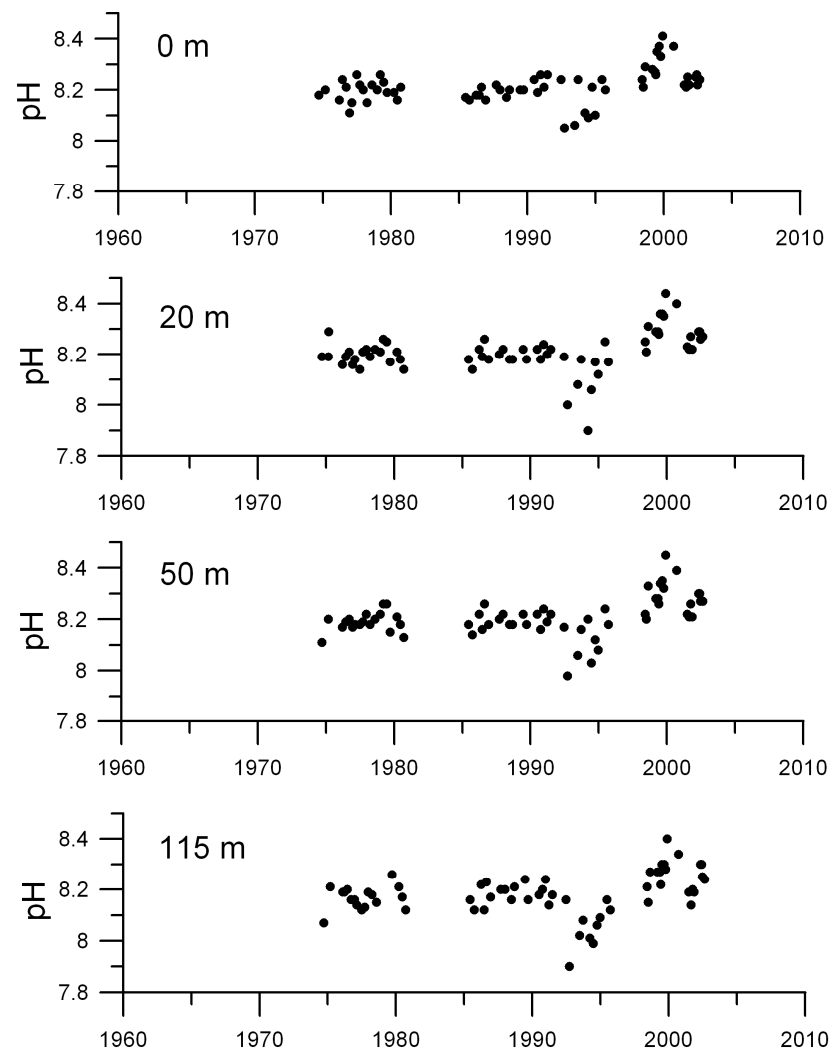

Fig. 6. Time series of $\mathrm{pH}$ values recorded at different depths of station P5.

crease towards the maximum productivity layer at $20-30 \mathrm{~m}$, where they have a positive value of $0.15-0.20 \mu \mathrm{moll}^{-1} \mathrm{yr}^{-1}$.

The largest anomaly in the 1990s can be found in nutrient data, coupled with a drop in $\mathrm{pH}$ values in deep layers (Fig. 6). An increase of deep orthophosphates, TIN and orthosilicates concentrations took place in 1991 and generally reached a maximum in 1994 and 1995. Orthophosphates increased significantly in the mid-1990s, especially at the southern parts of the transect (Fig. 4). Simultaneously, a strong negative peak in $\mathrm{pH}$ values (7.9-8.0) has been recorded. TIN and orthosilicates follow the same rates and patterns of increase in deep layers. Some differences in the anomaly rates can be found between the stations due to differences in processes they capture, but it is apparent from the data that a basin-scale process is driving all of these changes, from thermohaline properties, through oxygen and nutrient changes. We will try to ascribe these changes to the Ionian circulation variability and to the EMT-driven changes of the inflowing Adriatic currents.

We have estimated averages of all parameters during the whole studied interval (1961-2010) and during the 1991 to 1998 time interval, when the EMT- and BiOS-driven changes in the Mediterranean were found to influence the South Adriatic Sea (Gačić et al., 2010; Civitarese et al., 2010). Figure 7 portrays a classical hydrographic picture known to occur over the Palagruža Sill transect (e.g. Buljan and Zore-Armanda, 

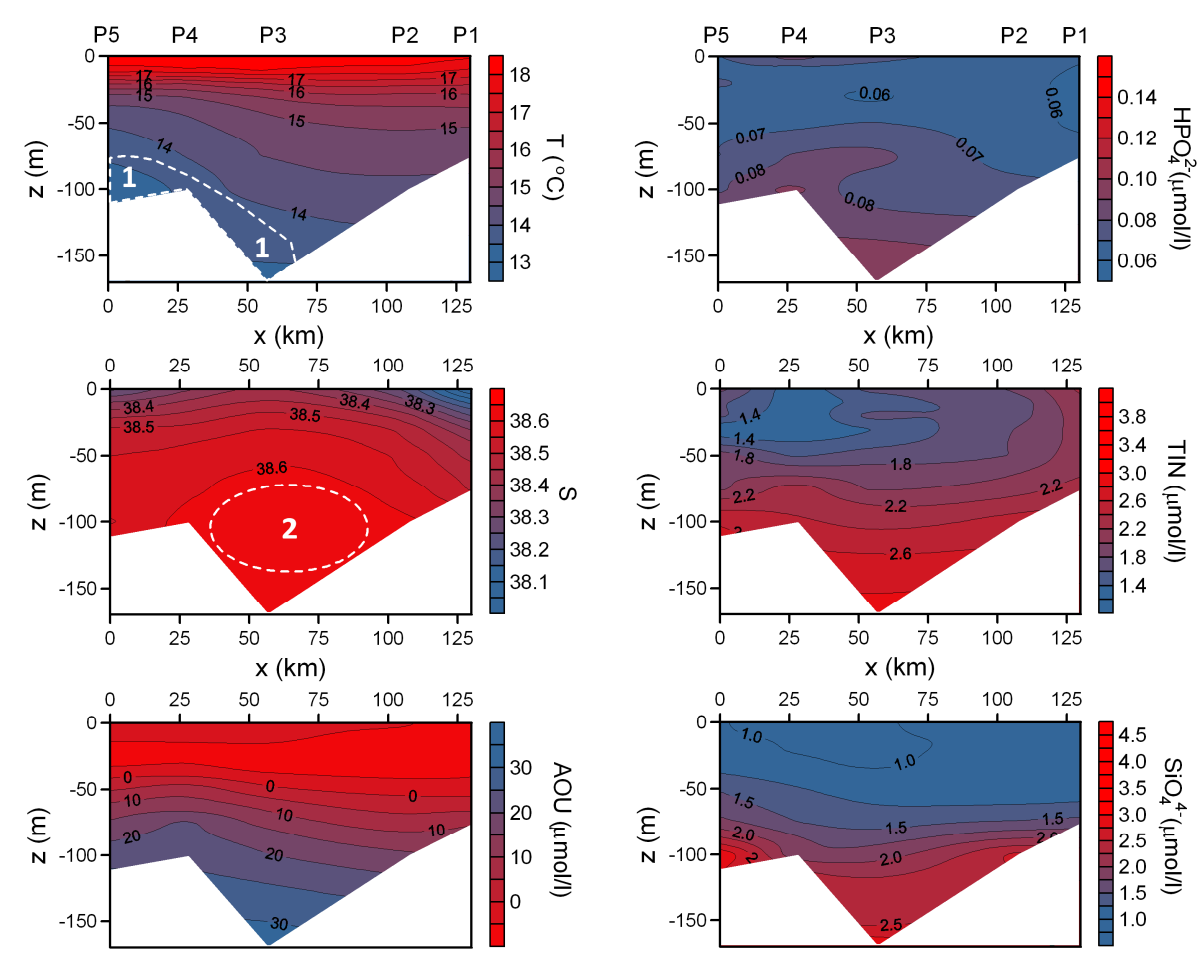

Fig. 7. Palagruža Sill profiles of temperature, salinity, AOU, orthophosphates, TIN and orthosilicates, averaged between 1960 and 2010. NAdDW outflow area is marked by 1 , and LIW core area by 2 . South is to the left.

1976; Artegiani et al., 1997): (1) deep temperature gradient, where the colder waters close to the western shore are a result of the NAdDW outflow, while warmer waters along the eastern shore are a result of the LIW inflow, driving the deep Adriatic thermohaline circulation; (2) salinity maximum over the deepest part of the transect, ascribed to a core of the LIW inflow; and (3) freshened surface waters that are a result of the outflow of the northern (southern part of the transect) and eastern (northern part of the transect) Adriatic rivers, which drive the Adriatic cyclonic surface circulation. AOU values exhibit the maximum values in the first $30-50 \mathrm{~m}$ of the water column, where the primary production maximum normally occurs (Marasović et al., 2005), decreasing towards the deep layers. The minimum in all nutrients may be found in the first $50 \mathrm{~m}$, the values increasing towards the bottom. The strongest vertical gradient in nutrients, i.e. nutricline, is positioned around $100 \mathrm{~m}$, already documented by Civitarese et al. (2010) for the southern parts of the Adriatic.

Comparison of the 1991-1998 and the all-data averages exhibits a significantly different picture of hydrographic and chemical properties along the transect (Fig. 8). Except for the first $10 \mathrm{~m}$, the temperature was significantly lower during the $1991-1998$ interval, up to $-0.7^{\circ} \mathrm{C}$ along the southern part of the transect. The salinity decreased everywhere, except in the very surface of the station P1. The decrease is as large as -0.1 , larger in the intermediate northern (station P1) than southern (station P4) waters. The AOU changes are par- ticularly interesting, mostly characterized by a decrease (up to $10 \mu \mathrm{moll}^{-1}$ ) along the southern stations and no changes along the northern stations in the first $50 \mathrm{~m}$, and by a strong increase in the deep waters (up to $20 \mu \mathrm{moll}^{-1}$ ).

Orthophosphates exhibited a significant increase during the 1991-1998 period, from $30 \%$ along the northern up to $100 \%$ along the southern section of the transect. The orthophosphates average values at the bottom of stations P3 to P5 were higher than $0.12 \mu \mathrm{moll}^{-1}$, much higher than the documented values for the open Middle Adriatic (Šolić et al., 2008) and even for the open northern Adriatic (Zavatarelli et al., 1998), where a significant orthophosphate input from rivers is evidenced (Lipizer et al., 2011). TIN values did not change significantly, except at the very bottom of stations P2 and P3. Nevertheless, TIN decrease in the surface layer (up to $25 \%$ ) between 1991 and 1998 and an increase towards the bottom (up to $40 \%$ ) are apparent along the transect, with a no-change-line stretching along $50 \mathrm{~m}$ depth. Orthosilicate concentrations did not change significantly in the upper $50 \mathrm{~m}$, but they increased significantly towards the bottom, especially at stations P3 and P5.

The ratio between TIN and orthophosphates (Fig. 9) over the common period of their data is characterized by lower values in the surface layer (up to $50 \mathrm{~m}$ ), where the primary production is taking place, and higher values in the bottom waters (ratio up to 35:1 at the bottom of station P2). The ratio is everywhere above $16: 1$, suggesting phosphate-limited 

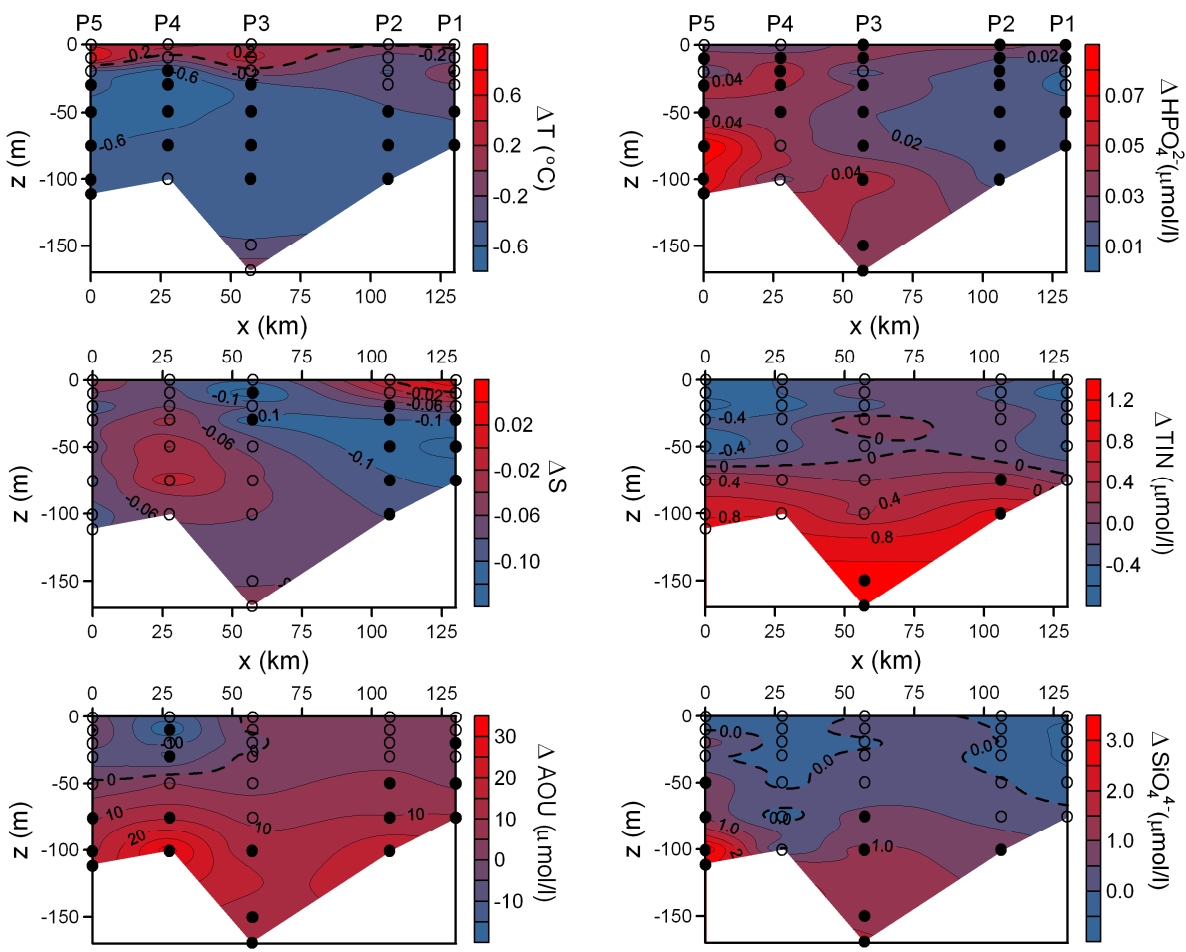

Fig. 8. As in Fig. 7, but for difference between 1991-1998 and 1960-2010 period. Full circles denote significant difference between two periods at $95 \%$ level.
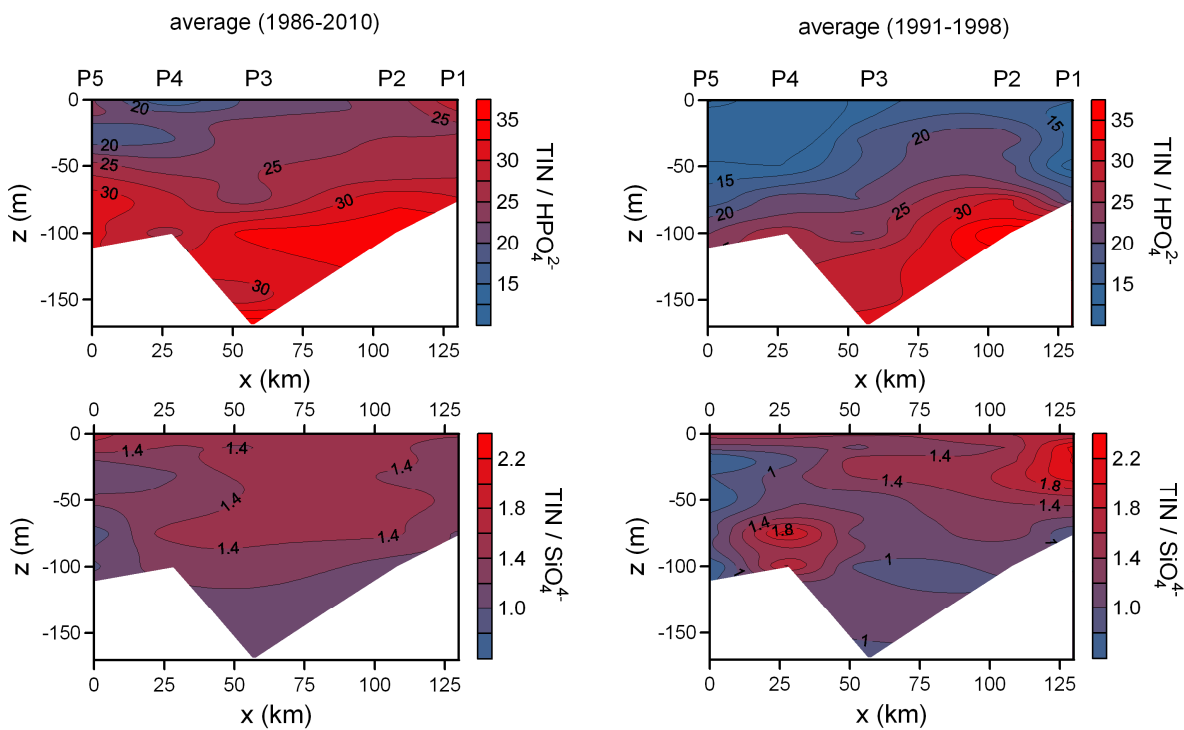

Fig. 9. Palagruža Sill profiles of TIN to $\mathrm{HPO}_{4}^{2-}$ and $\mathrm{TIN}$ to $\mathrm{SiO}_{4}^{4-}$ ratios averaged over common period of measurements $1986-2010$ (left panels) and over 1991-1998 (right panels).

conditions for primary production. The TIN to $\mathrm{HPO}_{4}^{2-}$ ratio decreased between 1991 and 1998, mostly in the surface waters, where the ratio was below $16: 1$ and occasionally decreased to 10:1, indicating the transition toward the nitrogen-limited conditions for primary production. The TIN to $\mathrm{SiO}_{4}^{4-}$ ratio is spatially stable during the $1960-2010$ pe- riod, between 1.3:1 and 1.5:1, which is in accordance with ratios found in the Eastern Mediterranean (e.g. Ribera d'Alcala et al., 2003). A decrease in the ratio can be found at most of the profiles between 1991 and 1998, expect at the surface of $\mathrm{P} 1$ and $\mathrm{P} 2$, and bottom of $\mathrm{P} 4$. The $\mathrm{SiO}_{4}^{4-}$ to $\mathrm{HPO}_{4}^{2-}$ ratio (not 
shown) is 20:1 on average, but ranges from 15:1 (surface waters) to 35:1 (deep waters).

\section{Discussion}

\subsection{Adriatic ingressions and the EMT}

There are two theories about the Adriatic ingressions, i.e. decadal variations in salinity of the Adriatic, which are presently discussed in the literature: (1) the salinity variations are a result of pulsation of the LIW towards the Adriatic, i.e. oscillations in the Otranto Strait along-strait transport are driving salinity fluctuations in the Adriatic, as originally raised by Buljan (1953) and further developed by a number of authors (e.g. Grbec et al., 2003); and (2) the salinity fluctuations are associated with different water masses entering the Adriatic, driven by the BiOS and circulation in the northern Ionian Sea (Gačić et al., 2010; Civitarese et al., 2010). An affirmative argument for the first hypothesis is the increased productivity in the Middle Adriatic, which partially coincided with the Eastern Mediterranean Transient. Namely, Grbec et al. (2009) document increased mean productivity at station P2 between 1980 and 1996, increasing up to 1986, and thereafter decreasing towards 1996. The increase in productivity before the EMT has been associated with the nutrient transport to the euphotic layer through vertical nutrient dynamics. On the other hand, Civitarese et al. (2010) found that nitrate and salinity in the Ionian and South Adriatic Seas have been out of phase for the last 20 years (i.e. high salinities are coupled with low nutrient concentrations and vice versa), suggesting that different water masses enter the Adriatic during low and high salinity periods rather than block the inflow in progress during low salinity periods. Moreover, they referred the maximum of the Ionian and South Adriatic nutrients observed in 1990s to the uplifting of the nutricline along the perimeter of the North Ionian anticyclonic gyre. Their assessment of available data on the Adriatic biodiversity supports the advection of waters from the Western Mediterranean to the Adriatic during the anticyclone circulation in the Northern Ionian Sea. However, they assumed that the advection is restricted to the surface nutrient-depleted waters only, which can be normally found meandering in the Ionian Sea (Malanotte-Rizzoli et al., 1997).

Our findings are in favour of the second hypothesis that connects the variations in the Adriatic thermohaline properties to different water masses and regimes in the Northern Ionian related to the $\mathrm{BiOS}$, although the observed nutrients, nutrient ratios and $\mathrm{pH}$ values do not follow the nutrient dynamic explanations raised by Civitarese et al. (2010). Namely, low salinity and temperature observed between 1991 and 1998 along the Palagruža Sill were accompanied by significantly larger orthophosphates (Fig. 8), which are known not to be controlled by the Adriatic sources (partially controlled just in the northern Adriatic, Degobbis and Gillmartin, 1990; De- gobbis et al., 2000), but rather by the waters inflowing from the Eastern Mediterranean (e.g. Buljan and Zore-Armanda, 1976; Krom et al., 2004, 2010). Accordingly, the observed decrease in the N:P (TIN to $\mathrm{HPO}_{4}^{2-}$ ) ratio and rather low $\mathrm{pH}$ values, which peaked in mid-1990s, cannot be explained by assuming vertical uplift of the Eastern Mediterranean nutrients along the Northern Ionian anticyclone, as the observed properties do not belong to the Eastern Mediterranean deep waters (Krom et al., 1991, 2004, 2010). Also, nutrientdepleted surface waters of Atlantic origin (so-called modified Atlantic water, Civitarese et al., 2010), which are dragged into the Adriatic through the BiOS, cannot contribute much to the observed high levels in nutrients; they are also characterised by higher DO content than observed at the sill. Therefore, our search for the source is directed to the adjacent Western Mediterranean waters, which reside below the euphotic layer. Namely, in the upper few hundred meters below the euphotic level, the Western Mediterranean orthophosphate concentrations are 2-5 times higher and in the deep waters about 2 times higher than the Eastern Mediterranean ones (Pujo-Pay et al., 2011). Also, nitrate and nitrite concentrations are about 2 times higher in the Western than in the Eastern Mediterranean, while ammonia concentrations are similar (Pujo-Pay et al., 2011). Finally, the N:P ratio is lower in the Western than in the Eastern Mediterranean (Pujo-Pay et al., 2011). The result is an east-west gradient of TIN and orthophosphates along the Sicily Strait.

The Sicily Strait, with maximum connecting depth of about $550 \mathrm{~m}$ (Gasparini et al., 2005), exhibits normally two water mass exchanges, with an inflow of less saline waters to the Eastern Mediterranean in the upper $200 \mathrm{~m}$, and outflow of deep saline LIW waters below. The EMT affected significantly the transport over the strait: massive generation of dense waters in the Aegean during the EMT induced quite strong salinity increase in the strait, accompanied by hydraulically-dragged vein of very dense bottom water( referred to as the old Eastern Mediterranean deep water) uplifted to the upper deep layers (Astraldi et al., 2001). By applying a simple mass conservation balance model, Gasparini et al. (2005) pointed out that the massive outflow of saline Eastern Mediterranean waters observed in 1992 should have been coupled with rather strong inflow of fresher-than-usual upper layer waters, to keep the mass balance in the strait. Moreover, a massive outflow of dense water from a basin is known to generate a lagged response of a thermohaline cell in anti-estuarine circulation systems. It is known that the Adriatic dense water outflow, occurring during winter and spring, induces a peak in the counter-flow lagging for several months (Orlić et al., 2007). Aside from the difference in size of the Adriatic and Eastern Mediterranean Basins and their thermohaline cells, the same physics is presumably present during massive generation of dense waters in the Eastern Mediterranean: the EMT generated a massive outflow to the Western Mediterranean over the Sicily Strait, presumably inducing a lagged massive counter-transport of waters in the upper 
layer. Thus, the amount of the Western Mediterranean waters that entered the Eastern Mediterranean during and after the EMT is much larger than during the non-EMT conditions and, once dragged into the Eastern Mediterranean, these waters are downwelled topographically to a greater depth, where their chemical properties are not influenced significantly by the biological activity.

Therefore, our assumption is that the Western Mediterranean waters, dragged over the Sicily Strait during and after the EMT, presumably entered the Adriatic through the northwestern branch of the anticyclonic circulation in the northern Ionian Sea; the circulation was additionally intensified by the EMT in early 1990s (Borzelli et al., 2009). The inflow stopped in 1997 when the reversal of the northern Ionian circulation happened due to the internal feedback process (Gačić et al., 2010). These waters consisted of surface nutrient-depleted waters, which were affected strongly by biological activity, and intermediate waters flowing below the euphotic layer, which did not change significantly on their way to the Adriatic. The latter waters were characterized by quite low dissolved oxygen content (Fig. 8), which, through upwelling at the shallower Palagruža Sill, strongly changed physical and chemical characteristics of the deep layer at the sill (decrease in temperature and salinity, increase in nutrient concentrations, change in $\mathrm{N}: \mathrm{P}$ ratio, decrease in $\mathrm{pH}$ values).

\subsection{Uniqueness of the 1991-1998 period}

Although time series of all nutrients do not cover the whole 61-year period (1960-2010), the data still allow us to discuss the uniqueness of the 1991-1998 period. Gačić et al. (2010) developed the theory that the BiOS is a decadal oscillation, but did not say anything about long-term variability in strength of the process. Civitarese et al. (2010) did a thorough investigation of existing literature on biodiversity changes in the Adriatic serving as a proxy for the circulation regimes and found that the Western Mediterranean organisms were found in the Adriatic during anticyclonic circulation in the northern Ionian Sea, while the Eastern Mediterranean organisms were observed during the LIW inflow and cyclonic circulation in the northern Ionian Sea; however, sparse data were available before 1990s (see their Table 2), while most of the data cover the last 20 years when the EMT occurred. Also, there are some papers that consider the EMT to be a climate shift (e.g. Conversi et al., 2010), indicating uniqueness of the process; on the other hand, Gačić et al. (2011) raise a possibility that the EMT may repeat when the preconditioning and severe wintertime cooling and winds coincide. High-resolution numerical modelling partially supports the latter: Beuvier et al. (2010) applied the eddy-permitting numerical model for the 1960-2000 period and found that the EMT is dominantly driven by winds and surface fluxes over the Aegean, which were uniquely extreme during winters of 1991 and 1992, but which may repeat with longer return period than the investigated time interval in the future.

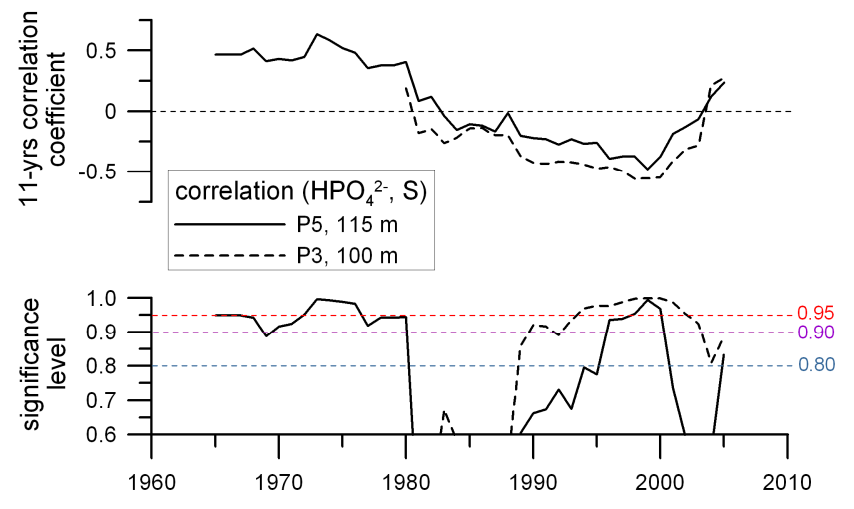

Fig. 10. Time series of 11-year running linear correlation coefficients between salinity and orthophosphates, and associated significance levels estimated for deep layers of stations P3 and P5.

Our data show that the orthophosphates, which were measured during the whole period at some stations, reached the highest levels in mid-1990s (Figs. 3 and 5), accompanied by maxima in other nutrients in deep layers at almost all stations. Apart from the mid-1990's maximum of nutrient concentrations, a decadal variability may be found during the whole interval, partially following the changes of thermohaline properties and dissolved oxygen content. Namely, a weak minimum in temperature and salinity values may be found in 1973-1974, accompanied by a maximum in TIN and orthophosphates (Fig. 3). On the other hand, an increase in TIN and orthophosphates in 1978-1979 did not merge with the salinity and temperature minimum (Figs. 3 and 4 ), and even coincided with the salinity maximum. Therefore, complex interactions between hydrographic and nutrient changes should be considered when assessing regular climate oscillations in the Middle Adriatic ecosystem, which are driven not only by the $\mathrm{BiOS}$, but also by the Adriatic biogeochemistry, by advection of inorganic and organic material from the northern Adriatic and coastal regions, by vertical mixing and nutrient redistribution, and by uptakes from the atmosphere.

However, a strong support to the uniqueness of the oceanographic and nutrient changes observed in mid-1990 can be found when correlating orthophosphates and salinity in deep parts of the Palagruža Sill (Fig. 10). Positive correlations can be found before 1980s, indicating that nutrient-rich waters lying below euphotic layer were normally advected to the sill. The intermediate waters in the South Adriatic (200$800 \mathrm{~m}$ ) are more saline than the waters residing in the first $200 \mathrm{~m}$, with salinity maximum at 200-300 m (Artegiani et al., 1997), while the nutricline is usually positioned at smaller depths, 50-150 m (Civitarese et al., 2010). Accordingly, the topographic upwelling occurring at the Palagruža Sill is dragging more saline and nutrient-rich waters from deeper layers, preserving the positive correlation between salinity and nutrients. Nevertheless, the correlations became the opposite 
in 1990s, i.e. lower-than-average salinity waters were characterised by higher-than-average nutrients $\left(\mathrm{HPO}_{4}^{2-}\right)$, which cannot be explained by an uplifting of the nutricline but only with advection of an intermediate water with different physical and chemical characteristics. These findings are congruent with the hypothesis that the Western Mediterranean waters residing below the euphotic zone, having lower salinity and DO content, higher nutrient ratio and lower $\mathrm{N}: \mathrm{P}$ ratio than the Eastern Mediterranean waters, were advected to the Palagruža Sill.

\subsection{Primary production and the EMT}

One would expect that the increase in available nutrients between 1991 and 1998, especially orthophosphates which are known to limit the primary production in the Adriatic and Eastern Mediterranean (Krom et al., 1991), would result in higher production rates. Indeed, Grbec et al. (2009) documented higher-than-average yearly and spring-summer primary production in this period at station P2 (precisely between 1991 and 1996) but preceded by similarly high production rates, which started in 1980. Even more, the 19801996 period is recognized by Grbec et al. (2009) as a climate shift in primary production; however, the analyses were based on the data collected at station P2 and another coastal station. Our chemical data support the documented higher production rates, potentially being a consequence of the EMT, as the TIN concentrations are lower-than-average, and therefore nitrogen consumption is higher-than-average in the euphotic zone between 1991 and 1998 (Fig. 8) over the whole Palagruža Sill profile. The increase in nitrogen consumption is presumably a result of much higher availability of phosphorus, which shifted normal phosphorus-limited primary production conditions towards the nitrogen-limited conditions. In addition, the 1991-1998 AOU concentrations generally decreased at the level of maximum (20-30 m depth) along the southern part of the section, indicating higher primary production rates driven by a significant nutrient load.

Larger orthophosphate concentrations and the documented higher primary production rates (Grbec et al., 2009) presumably shifted the Adriatic to the less oligotrophic conditions, resulting in the N:P ratio close to the Redfield ratio of 16:1 or less. Namely, the 1991-1998 N:P ratio in most of the euphotic zone is below $16: 1$, even coming close to $10: 1$ in the southern section. Therefore, the primary production along most of the section was controlled by nitrogen availability between 1991 and 1998. A possibility that nitrogen-limited conditions in primary production can occur in the open Middle Adriatic has been already suspected by Šolić et al. (2008), who found a positive correlation between different biological parameters and nitrogen at station P2 between 1997 and 2006.

What is still unclear here is a reason for increased primary production observed between 1980 and 1990 (Grbec et al., 2009), as the nutrients along the transect did not differ much from their average values, and the production was limited by phosphorus. It is known that more efficient vertical mixing, deep convection and a transport of deep nutrients towards euphotic zone may trigger primary production (Gačić et al., 2002; Civitarese et al., 2005). A series of severe winters occurred between 1981 and 1983 with quite anomalous heat and buoyancy fluxes in the Adriatic Sea (Josey, 2003). Furthermore, a shift in water mass characteristics was detected in the South Adriatic Pit in 1980s (Vilibić and Orlić, 2001). However, this scenario should be further investigated and confirmed.

\subsection{Impact on the higher trophic organisms}

A lot of implications arise from the fact that the Western Mediterranean waters may be transported to the Adriatic and significantly raise the nutrient levels there. An increase of nutrients in the euphotic layer is a prerequisite for higher primary production, which may impact the abundance of higher trophic organisms, up to the fish stock. Indeed, Kraus and Supić (2011) presented the anchovy catchment in the Adriatic Sea between 1990 and 2004, found the minimum in 1996, and then a sharp increase (about ten times) in the following 3 years. Cingolani et al. (1996) documented much higher anchovy biomass for the period 1976-1984 than for the period 1987-1992. Santojanni et al. (2006) connected these variations with different atmospheric and hydrological variables, but we believe that a coincidence of high primary production between 1980 and 1996, anchovy collapse between 1985 and 1997 and recovery after that, and nutrient changes observed in the Adriatic are connected, which should be carefully investigated in the future.

Another important finding is a constant decrease of the dissolved oxygen and increase in AOU values at deep layers in the last 50 years, which is mainly a footprint of less effective ventilation of deep layers. The trends are quite strong and coherent with the literature, which documents deoxygenisation trends over the World Ocean, particularly strong in coastal regions (Gilbert et al., 2010). The lower-than-average AOU values that characterized the deep waters at the Palagruža Sill in mid-1990s amplify the effect of trends. Therefore, deep pelagic and benthic organisms can suffer from these changes, especially within biodiversity niches such is Jabuka Pit (Fig. 1) (e.g. Vrgoč et al., 2004) - a multi-depression complex system collecting dense water from the northern Adriatic, horizontally mixing with intermediate waters coming from the southeast and occasionally being ventilated through severe cooling and wind-induced mixing acting from the surface (Vilibic et al., 2004), and therefore sensitive to changes in physical and chemical parameters. 


\section{Summary and conclusions}

We investigated long-term series (1960-2010) of different physical and chemical parameters along the Palagruža Sill transect, which is to our knowledge the best dataset that can be used for assessing climate conditions, shifts and fluctuations of the open Adriatic Sea. Aside from documenting known and characteristic properties, an anomaly in nutrients occurring between 1991 and 1998 came into the focus. Several important conclusions may be raised:

- A large increase of deep nutrient concentrations (below euphotic zone) along the transect was observed between 1991 and 1998, especially of orthophosphates, accompanied by lower-than-usual temperature, salinity and higher-than-usual apparent oxygen utilization values. The N:P ratio decreased significantly during this period, accompanied by a decrease in $\mathrm{pH}$ values. As observed nutrient and $\mathrm{pH}$ changes cannot have their origin in the Eastern Mediterranean, we conclude that the Western Mediterranean waters, rich in orthophosphates, TIN and having lower $\mathrm{pH}$ values when compared to the Eastern Mediterranean waters, were dragged to the Adriatic through anticyclonic circulation in the northern Ionian Sea. Aside the known flow in the euphotic layer, referring in literature to modified Atlantic water (e.g. Malanotte-Rizzoli et al., 1997; Gasparini et al., 2005), the flow presumably encompassed the waters lying below the euphotic layer as being characterized by low oxygen content. However, support for the hypothesis from numerical modelling exercises and quantification of the phenomenon should be undertaken in future research.

- No similar conditions have been documented between 1960 and 2010 in the Middle Adriatic, supporting the uniqueness of the 1991-1998 time interval in terms of nutrient dynamics. This period coincided with the EMT period, which generated massive sinking of dense waters to the deep Ionian, forcing anticyclonic circulation of the basin. Therefore, a prerequisite for the observed high nutrient transport from the Western Mediterranean to the Adriatic is presumably achieved through simultaneous acting of the EMT, which is unique by itself, and a right phase (anticyclonic circulation in the northern Ionian) of the BiOS.

- The 1991-1998 period has been characterised by nitrogen-limited conditions for primary production over most of the transect, opposing typical phosphoruslimited conditions found in the rest of the examined period, and normal for the Eastern Mediterranean.

- Increased nutrient concentrations may partially explain the documented maximum in primary production, i.e. the maximum between 1991 and 1996, but not between
1980 and 1990. The latter is a result of some other processes, of which the most promising is enhanced vertical mixing and transport of nutrients to the euphotic layer, but this should be further investigated in future.

Acknowledgements. We thank the oceanographers and other staff involved in the collection of physical and chemical data in the middle Adriatic. The comments raised by two anonymous reviewers and Giuseppe Civitarese and Miroslav Gacic are highly appreciated. A support for the study has been provided through the EU FP7 funded project PERSEUS (Policy-Oriented Marine Environmental Research in the Southern European Seas), and through Ministry of Science, Education and Sports of the Republic of Croatia (Grants 001-0013077-1122 and 001-0013077-0845).

Edited by: G. Herndl

\section{References}

Artegiani, A., Bregant, D., Paschini, E., Pinardi, N., Raicich, F., and Russo, A.: The Adriatic Sea general circulation. Part I: airsea interactions and water mass structure, J. Phys. Oceanogr., 27, 1492-1514, 1997.

Astraldi, M., Gasparini, G. P., Gervasio, L., and Salusti, E.: Dense water dynamics along the Strait of Sicily (Mediterranean Sea), J. Phys. Oceanogr., 31, 3457-3475, 2001.

Beuvier, J., Sevault, F., Herrmann, M., Kontoyiannis, H., Ludwig, W., Rixen, M., Stanev, E., Beranger, K., and Somot, S.: Modeling the Mediterranean Sea interannual variability during 1961-2000: Focus on the Eastern Mediterranean Transient, J. Geophys. Res., 115, C08017, doi:10.1029/2009JC005950, 2010.

Borzelli, G. L. E., Gačić, M., Cardin, V., and Civitarese, G.: Eastern Mediterranean Transient and reversal of the Ionian Sea circulation, Geophys. Res. Lett., 36, L15108, doi:10.1029/2009GL039261, 2009.

Buljan, M.: Fluctuation of salinity in the Adriatic. Izvještaj Republičke Ribarstveno-biološke ekspedicije "Hvar" 1948-1949, Acta Adriatica, 2, 1-64, 1953.

Buljan, M. and Zore-Armanda, M.: Oceanographic properties of the Adriatic Sea, Oceanography and Marine Biology-Annual Review, 14, 11-98, 1976.

Campanelli, A., Grilli, F., Paschini, E., and Marini, M.: The influence of an exceptional Po River flood on the physical and chemical oceanographic properties of the Adriatic Sea, Dynamics of the Atmospheres and Oceans, 52, 284-297, 2011.

Cingolani, N., Giannetti, G., and Arneri, E.: Anchovy fisheries in the Adriatic Sea, Scientia Marina, 60, Supl. 2, 269-277, 1996.

Civitarese, G., Gačić, M., Cardin, V., and Ibello, V.: Winter convection continues in the warming Southern Adriatic, EOS Transactions, 86, 445-451, 2005.

Civitarese, G., Gačić, M., Lipizer, M., and Eusebi Borzelli, G. L.: On the impact of the Bimodal Oscillating System (BiOS) on the biogeochemistry and biology of the Adriatic and Ionian Seas (Eastern Mediterranean), Biogeosciences, 7, 3987-3997, doi:10.5194/bg-7-3987-2010, 2010.

Conversi, A., Umani, S. F., Peluso, T., Molinero, J. C., Santojanni, A., and Edwards, M.: The Mediterranean Sea 
regime shift at the end of the 1980s, and intriguing parallelisms with other European basins, PLOS ONE, 5, e10633, doi:10.1371/journal.pone.0010633, 2010.

Crispi, G., Mosetti, R., Solidoro, C., and Crise, A.: Nutrients cycling in Mediterranean basins: the role of the biological pump in the trophic regime, Ecological Modelling, 138, 101-114, 2001.

Degobbis, D. and Gilmartin, M.: Nitrogen, phosphorus and silicon budgets for the northern Adriatic Sea, Oceanologica Acta, 13, 31-45, 1990.

Degobbis, D., Precali, R., Ivančić, I., Smodlaka, N., Fuks, D., and Kveder, S.: Long-term changes in the northern Adriatic ecosystem related to anthropogenic eutrophication, Int. J. Environment Pollut., 13, 495-533, 2000.

Gačić, M., Civitarese, G., Miserocchi, S., Cardin, V., Crise, A., and Mauri, E.: The open-ocean convection in the Southern Adriatic: a controlling mechanism of the spring phytoplankton bloom, Cont. Shelf Res., 22, 1897-1908, 2002.

Gačić, M., Borzelli, G. L. E., Civitarese, G., Cardin, V., and Yari, S.: Can internal processes sustain reversals of the ocean upper circulation? The Ionian Sea example, Geophys. Res. Lett., 37, L09608, doi:10.1029/2010GL043216, 2010.

Gačić, M., Civitarese, G., Eusebi Borzelli, G. L., Kovačević, V., Poulain, P.-M., Theocharis, A., Menna, M., Catucci, A., and Zarokanellos, N.: On the relationship between the decadal oscillations of the northern Ionian Sea and the salinity distributions in the eastern Mediterranean, J. Geophys. Res., 116, C12002, doi:10.1029/2011JC007280, 2011.

Gasparini, G. P., Ortona, A., Budillon, G., Astraldi, M., and Sansone, E.: The effect of the Eastern Mediterranean Transient on the hydrographic characteristics in the Strait of Sicily and in the Tyrrhenian Sea, Deep-Sea Res. I, 52, 915-935, 2005.

Gilbert, D., Rabalais, N. N., Díaz, R. J., and Zhang, J.: Evidence for greater oxygen decline rates in the coastal ocean than in the open ocean, Biogeosciences, 7, 2283-2296, doi:10.5194/bg-72283-2010, 2010.

Grasshoff, K.: Methods of Seawater Analysis, Verlag Chemie, New York, 307 pp., 1976.

Grbec, B., Morović, M., and Zore Armanda, M.: Mediterranean Oscillation and its relationship to salinity fluctuation in the Adriatic Sea, Acta Adriatica, 44, 61-76, 2003.

Grbec, B., Morović, M., Paklar, G. B., Kušpilić, G., Matijević, S., Matić, F., and Ninčević Gladan, Ž.: The relationship between the atmospheric variability and productivity in the Adriatic Sea area, J. Marine Biol. Association of the United Kingdom, 89, 15491558, 2009.

Grilli, F., Marini, M., Degobbis, D., Ferrari, C. R., Fornasiero, P., Russo, A., Gismondi, M., Djakovac, T., Precali, R., and Simonetti, R.: Circulation and horizontal fluxes in the northern Adriatic Sea in the period June 1999-July 2002. Part II: Nutrients transport, Sci. Total Environ., 353, 115-125, 2005.

Josey, S. A.: Changes in the heat and freshwater forcing of the eastern Mediterranean and their influence on deep water formation, J. Geophys. Res., 108, 3237, doi:10.1029/2003JC001778, 2003.

Klein, B., Roether, W., Manca, B.B., Bregant, D., Beitzel, V., Kovačević, V., and Luchetta, A.: The large deep water transient in the Eastern Mediterranean, Deep-Sea Res. I, 46, 371-414, 1999.

Klein, B., Roether, W., Civitarese, G., Gačić, M., Manca, B. B., and Ribera d'Alcala, M.: Is the Adriatic returning to dominate the production of Eastern Mediterranean Deep Water?, Geophys.
Res. Lett., 27, 3377-3380, 2000.

Kraus, R. and Supić, N.: Impact of circulation on high phytoplankton blooms and fish catch in the northern Adriatic (1990-2004), Estuarine Coastal and Shelf Science, 91, 198-210, 2011.

Kress, N., Manca, B. B., Klein, B., and Deponte, D.: Continuing influence of the changed thermohaline circulation in the eastern Mediterranean on the distribution of dissolved oxygen and nutrients: Physical and chemical characterization of the water masses, J. Geophys. Res., 108, 8109, doi:10.1029/2002JC001397, 2003.

Krom, M. D., Kress, N., and Brenner, S.: Phosphorus limitation of primary productivity in the eastern Mediterranean Sea, Limnol. Oceanogr., 36, 424-432, 1991.

Krom, M. D., Herut, B., and Mantoura, R. F. C.: Nutrient budget for the Eastern Mediterranean: Implications for phosphorus limitation, Limnol. Oceanogr., 49, 1582-1592, 2004.

Krom, M.D. Emeis, K.-C., and Van Cappellen, P.: Why is the Eastern Mediterranean phosphorus limited?, Prog. Oceanogr., 85, 236-244, 2010.

Lascaratos, A., Williams, R. G., and Tragou, E.: A mixed-layer study of the formation of Levantine Intermediate Water, J. Geophys. Res., 98, 14739-14749, 1993.

Lipizer, M., Cossarini, G., Falconi, C., Solidoro, C., and Umani, S. F.: Impact of different forcing factors on N:P balance in a semienclosed bay: The Gulf of Trieste (North Adriatic Sea), Cont. Shelf Res., 31, 1651-1662, 2011.

Ludwig, W., Bouwman, A. F., Dumont, E., and Lespinas, F.: Water and nutrient fluxes from major Mediterranean and Black Sea rivers: past and future trends and their implications for the basin-scale budgets, Global Biogeochem. Cycle, 24, GB0A13, doi:10.1029/2009GB003594, 2010.

Malanotte-Rizzoli, P., Manca, B. B., Ribera d'Alcala, M., Theocaris, A., Bergamasco, A., Bregant, D., Budillon, G., Civitarese, G., Georgopoulos, D., Michelato, A., Sansone, E., Scarazzato, P., and Souvermezoglou, E.: A synthesis of the Ionian Sea hydrography, circulation and water mass pathways during POEM phase I, Prog. Oceanogr., 39, 153-204, 1997.

Marasović, I., Grbec, B., and Morović, M.: Long-term production changes in the Adriatic, Netherlands Journal of Sea Research, 34, 267-273, 1995.

Marasović, I., Ninčević, Ž., Kušpilić, G., Marinović, S., and Marinov, S.: Long-term changes of basic biological and chemical parameters at two stations in the middle Adriatic, J. Sea Res., 54, 3-14, 2005.

Marini, M., Grilli, F., Guarnieri, A., Jones, B. H., Klajic, Z., Pinardi, N., and Sanxhaku, M.: Is the southeastern Adriatic Sea coastal strip an eutrophic area?, Estuarine Coastal and Shelf Science, 88, 395-406, 2010.

Ninčević Gladan, Ž., Marasović, I., Grbec, B., Skejić, S., Bužančić, M., Kušpilić, G., Matijević, S., and Matić, F.: Inter-decadal variability in phytoplankton community in the Middle Adriatic (Kaštela Bay) in relation to the North Atlantic Oscillation, Estuaries and Coasts, 33, 376-383, 2010.

Orlić, M., Dadić, V., Grbec, B., Leder, N., Marki, A., Matić, F., Mihanović, H., Beg Paklar, G., Pasarić, M., Pasarić, Z., and Vilibić, I.: Wintertime buoyancy forcing, changing seawater properties and two different circulation systems produced in the Adriatic, J. Geophys. Res., 112, C03S07, doi:10.1029/2005JC003271, 2007.

Polimene, L., Pinardi, N., Zavatarelli, M., and Colella, S.: The Adriatic Sea ecosystem seasonal cycle: Validation of a three- 
dimensional numerical model, J. Geophys. Res., 112, C03S19, doi:10.1029/2005JC003260, 2006.

Pujo-Pay, M., Conan, P., Oriol, L., Cornet-Barthaux, V., Falco, C., Ghiglione, J.-F., Goyet, C., Moutin, T., and Prieur, L.: Integrated survey of elemental stoichiometry $(\mathrm{C}, \mathrm{N}, \mathrm{P})$ from the western to eastern Mediterranean Sea, Biogeosciences, 8, 883899, doi:10.5194/bg-8-883-2011, 2011.

Ribera d'Alcala, M., Civitarese, G., Conversano, F., and Lavezza, R.: Nutrient ratios and fluxes hint at overlooked processes in the Mediterranean Sea, J. Geophys. Res., 108, 8106, doi:10.1029/2002jc001650, 2003.

Roether, W., Manca, B. B., Klein, B., Bregant, D., Georgopoulos, D., Beitzel, V., Kovacevic, V., and Luchetta, A.: Recent changes in eastern Mediterranean deep waters, Science, 271, 333-335, 1996.

Roether, W., Klein, B., Manca, B. B., Theocharis, A., and Kioroglou, S.: Transient Eastern Mediterranean deep waters in response to the massive dense-water output of the Aegean Sea in the 1990s, Prog. Oceanogr., 74, 540-571, 2007.

Santojanni, A., Arneri, E., Bernardini, V., Cingolani, N., Di Marco, M., and Russo, A.: Effects of environmental variables on recruitment of anchovy in the Adriatic Sea, Climate Res., 31, 181-193, 2006.

Siokou-Frangou, I., Christaki, U., Mazzocchi, M. G., Montresor, M., Ribera d'Alcalá, M., Vaqué, D., and Zingone, A.: Plankton in the open Mediterranean Sea: a review, Biogeosciences, 7, 1543 1586, doi:10.5194/bg-7-1543-2010, 2010.

Solidoro, C., Bastianini, M., Bandelj, V., Codermatz, R., Cossarini, G., Canu, D. M., Ravagnan, E., Salon, S., and Trevisani, S.: Current state, scales of variability, and trends of biogeochemical properties in the northern Adriatic Sea, J. Geophys. Res., 114, C07S91, doi:10.1029/2008JC004838, 2009.

Strickland, J. D. H. and Parsons, T. R.: A practical handbook of sea-water analysis, J. Fisheries Research Board of Canada, 167, 1-311, 1972.
Šolić, M., Krstulović, N., Vilibić, I., Kušpilić, G., Šestanović, S., Šantić, D., and Ordulj, M.: The role of water mass dynamics in controlling bacterial abundance and production in the middle Adriatic Sea, Marine Environ. Res., 65, 388-404, 2008.

Thingstad, T. F., Krom, M. D., Mantoura, R. F. C., Flaten, G. A. F., Groom, S., Herut, B., Kress, N., Law, C. S., Pasternak, A., Pitta, P., Psarra, S., Rassoulzadegan, F., Tanaka, T., Tselepides, A., Wassmann, P., Woodward, E. M. S., Riser, C. W., Zodiatis, G., and Zohary, T.: Nature of phosphorus limitation in the ultraoligotrophic eastern Mediterranean, Science, 309, 1068-1071, 2005.

Vilibić, I. and Orlić, M.: Least-squares tracer analysis of water masses in the South Adriatic (1967-1990), Deep-Sea Res. I, 48, 2297-2330, 2001.

Vilibić, I. and Šantić, D.: Deep water ventilation traced by Synechococcus cyanobacteria, Ocean Dynam., 58, 119-125, 2008.

Vilibić, I. and Supić, N.: Dense water generation on a shelf: the case of the Adriatic Sea, Ocean Dynam., 55, 403-415, 2005.

Vilibić, I., Grbec, B., and Supić, N.: Dense water generation in the north Adriatic in 1999 and its recirculation along the Jabuka Pit, Deep-Sea Res. I, 51, 1457-1474, 2004.

Vilibić, I., Mihanović, H., Šepić, J., and Matijević, S.: Using SelfOrganising Maps to investigate long-term changes in deep Adriatic water patterns, Cont. Shelf Res., 31, 695-711, 2011.

Viličić, D., Šilović, T., Kuzmić, M., Mihanović, H., Bosak, S., Tomažić, I., and Olujić, G.: Phytoplankton distribution across the southeast Adriatic continental and shelf slope to the west of Albania (spring aspect), Environmental Monitoring and Assessment, 177, 593-607, 2011.

Vrgoč, N., Arneri, E., Jukić-Peladić, S., Krstulović Šifner, S., Mannini, P., Marčeta B., Osmani, K., Piccinetti, C., and Ungaro, N.: Review of current knowledge on shared demersal stocks of the Adriatic Sea, FAO-MiPAF Scientific Cooperation to Support Responsible Fisheries in the Adriatic Sea. GCP/RER/010/ITA/TD12, AdriaMed Technical Documents, 12, 91 pp., 2004.

Zavatarelli, M., Raicich, F., Bregant, D., Russo, A., and Artegiani, A.: Climatological biogeochemical characteristics of the Adriatic Sea, J. Marine Syst., 18, 227-263, 1998. 